Open Access

\title{
How do we conquer the growth limits of capitalism? Schumpeterian Dynamics of Open Innovation
}

JinHyo Joseph Yun

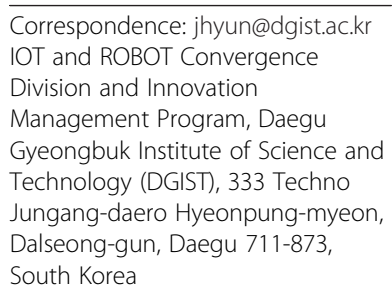

\begin{abstract}
The purpose of this study is to answer the research question, "How do we conquer the growth limits of capitalism?" Based on existing studies on growth limits of capitalism by Marx and Schumpeter as well as the recent discussions of Drucker, Rifkin, and Piketty, the dynamic model of an open innovation economy system (OIES) is proposed as an answer to this research question.

OIES consists of an open innovation economy, closed innovation economy, and social innovation economy. The dynamics of OIES occurs from the positive interaction among the open innovation economy, closed innovation economy, and social innovation economy. The dynamics of the OIES circle are from an open innovation economy, through a closed innovation economy and social innovation economy, and back to an open innovation economy again. In addition, the validation of the model for the dynamics of OIES is improved by simulating the life cycle of the dynamics of OIES, low-level OIES dynamics, and high-level OIES dynamics, and by inquiring about a practical economic system corresponding to each simulation situation. Next through a comparative discussion between the linear steps of Schumpeter 1 and 2, and Socialist Democracy, and the dynamics of an open Innovation economic system, the practical and theoretical characteristics of the dynamics of OIES are clearly defined. Finally, the limits of this study and a follow-up research project are presented in addition to a summary of the discussion.
\end{abstract}

Keywords: Open innovation economy system, Dynamics, Open innovation, Closed innovation, Social innovation

\section{Introduction}

\section{Capitalism at its growth limits}

As of March 2015, the growth of the global capitalistic economy has halted. Specifically, the base rate of each nation's capital investment, which is the standard for capital income that serves as the key of capitalism, is near $0.00 \%$. With this, the base rate of the capital investment of advanced nations in the area of capitalism has reached almost $0 \%$. The fact that the federal funds rate of the Federal Reserve Bank of United States is $0.00-0.25 \%$, the rate of the European Central Bank is $0.05 \%$, and the rate of the Bank of Japan is $0.1 \%$ serves as evidence for this standstill.

Korea is not an exception in this case because its base rate is only $1.75 \%$. Interest rates indicate that the expected income from capital investment is zero considering the

\section{Springer}

(c) 2015 Yun. Open Access This article is distributed under the terms of the Creative Commons Attribution 4.0 International License (http://creativecommons.org/licenses/by/4.0/), which permits unrestricted use, distribution, and reproduction in any medium, provided you give appropriate credit to the original author(s) and the source, provide a link to the Creative Commons license, and indicate if changes were made. 
population growth rate and inflation; thus, zero income, which is expected from capital investment, serves as an indicator for the ending of the growth of capitalism.

However, the base rate of China and India is relatively high, which is at $7.4 \%$ and $5 \%$, respectively. In proportion to the high interest rate, their national capital income records the annual average economic growth rate which is close to the interest rate. These exceptional cases should not be used to cover the fact that the growth of capitalism has already reached its limits. First, these nations do not thoroughly pursue the principle of a capitalist economy. They block capital investment in land because private ownership of land is prohibited, and their annual economic plan is formulated by a central government. Because of these facts, they have a market- and nation-led economic system rather than a market-driven economy. Second, in their cases, the history of introducing the market economy of capitalism is not that long, and they have not grown sufficiently to reach their growth limits. The latter case can be the basis of understanding the growth rate of a new capitalist nation with high growth in South America, Southeast Asia, and Africa.

In particular, if the contribution of inflation and population growth is subtracted from economic growth, it is observed that the economic growth rate of major capitalistic nations is reaching $0 \%$. Before the capitalistic economic system was introduced, a very low economic growth rate was recorded in the past. After the Industrial Revolution, early capitalistic markets recorded high economic growth rates (Piketty, 2014, p. 25). However, after the 1980s, the US, EU, and Japan recorded a low economic growth rate which was less than half of their respective rates over the past 20 years. Even though the quantity and distribution of technology and knowledge increased globally, and the world became flat because of global networks, the economic growth rate of major capitalistic nations decreased by more than half.

Since the mid-1990s, the global growth engine of capitalism has remained stagnant for the past 20 years. The stagnation of economic growth is sometimes interpreted as a continuation of the aftermath of the global real estate bubble caused by the subprime mortgage crisis. However, the real estate bubble itself was caused by the structural distortion of capitalism, coming from the growth stagnation of capitalism for which the expected income rate of capital investment is very low. Thus, it is not proper to interpret that the current stagnant growth of capitalism is the aftermath of the subprime mortgage crisis. A theoretical and practical discussion to define and interpret the growth stagnation of capitalism around the world is necessary to guarantee an alternative in handling the problem.

\section{Research question}

This study starts from the recognition that capitalism has reached its growth limits. Indeed, it is considered as part of the business cycle, and it can be seen that the growth of global capitalism has not reached its limits but has been on its decline in the business cycle. Global capitalism has reached the stagnation of its growth. To overcome it, Piketty said that the structure of distribution should be improved as a new alternative, and as part of it, he suggested a capital tax. His discussion corresponds to the growth limits of capitalism (Piketty, 2014). Meanwhile, Ha-Sung Chang mentioned that as capitalism in Korea moves away from its original characteristics, its soundness should 
be recovered through the political intervention of the government. His logic handles the limits of capitalism at a national level (Ha-Sung 2014). He also talked about the growth limits of capitalism by pointing out 23 things not told to anyone about capitalism (Chang, 2002, p. 14; 2010, p. 11).

Since the financial crisis in the 1990s, the gross domestic product (GDP) per capita of Korea has still been around USD 20,000 s for the past 20 years. However, the sales and profits of the top 10 or 30 companies that are listed have been at their highest level since the foundation of the country, and the current account surplus has also continued to rise, reaching its highest level in March 2015. Even in the good records, the Korean economy has shown its growth with a lower rate of new job creation. The US has achieved a relatively high economic growth of $3-4 \%$ and new job creation based on quantitative easing. In most European countries and in Japan, slow economic growth has continued to happen for a long time now.

The purpose of this study is to answer the research question, "How do we conquer the growth limits of capitalism?" In other words, the question of whether the growth of capitalism has reached its limits is not the subject of this study. However, to clearly identify this, the theory on the growth limits of capitalism is summarized. A discussion is given to secure the perceptual basis of a theory model on development to overcome the growth limits of capitalism, which is the key element of this study.

The research scope and method start from the analysis of existing studies on the growth limits of capitalism. The review of the preceding studies covers classic discussions on the growth limits of capitalism like that from Marx and Schumpeter as well as the recent discussions of Drucker, Rifkin, and Piketty. Second, the economy system model to overcome the growth limits of capitalism is set. During the establishment of the model, I joined the corporate business model innovation program of the Center for Executive Education at UC Berkeley on Nov. 17-19, 2014 and the India Innovation Festival held in the Indian Presidential Palace on March 6-13, 2015 wherein I applied the results of the participant observation to this study. In addition, this study is based on Schumpeter 1 and 2, Socialist Democracy, Ostrom's Comedy of Commons, Chesbrough's Open Innovation and Open Business Model, Corporate Social Responsibility (CSR), and Creating Shared Value (CSV). Third, various situations of the Dynamics of Open Innovation Economic system (OIES) based on thinking experiments are simulated. The theoretical validation of the model of the dynamics of OIES is improved by simulating the life cycle of the dynamics of OIES, low-level OIES dynamics, and high-level OIES dynamics, and by inquiring about the practical economic system corresponding to each simulation situation. Fourth, through a comparative discussion between the linear steps of Schumpeter 1 and 2 and Socialist Democracy, and the Dynamics of Open Innovation Economic system, the practical and theoretical characteristics of the dynamics of OIES are clearly defined. Fifth, the limits of this study and the follow-up research project are presented in addition to a summary of the discussion.

\section{Growth limits of capitalism, a literature review}

The discussion on the growth limits of capitalism is mainly rooted in the Decreasing Law of Surplus Value of Capital of Marx, Big Business and Socialist Democracy of Schumpeter, and General Theory of Employment, Interest, and Money of Keynes (Keynes, 1935; Marx, 1867; Schumpeter, 1934; 1939; 1942). Adam Smith introduced the concept of equilibrium 
to the capitalist economy and completed the self-purified market balance based on the price mechanism corresponding to the physical order of nature in theory. He formed the theoretical basis of the objection of growth limits of capitalism on the Neoclassical School of thought (Marx, 1867; Smith, 1937). As a matter of fact, Marx said that the balance achieved between the demand and the supply on the market is a very exceptional condition, and the market itself is inevitably imbalanced as described in the Capital, Volume II (Marx 1978a).

However, with the rapid increase in the decision power of the economic growth of technology and market in the global economy in the late $20^{\text {th }}$ century and $21^{\text {st }}$ century, discussions on the limits of capitalism have been suggested in various ways. For example, there are Drucker's post-capitalism, Ripkin's end of work and zero marginal cost, Piketty's acceleration of unbalanced distribution, and Ostrome's Comedy of Commons (Drucker, 1993; Ostrom, 1990; Piketty, 2014; Rifkin \& Kruger, 1996; Rifkin, 2014; Rifkin \& Kruger, 1996).

\section{Theoretical discussion on growth limits of capitalism in the $19^{\text {th }}$ century and early $20^{\text {th }}$ century}

Marx discussed the labor process and the process of producing the surplus value altogether (Marx, 1867, p. 197). According to him, the absolute surplus value and the relative surplus value are generated from labor, and they are converted into capital. Thus, the general law of capitalist accumulation originated from the accumulation of surplus value, and it is called primitive accumulation (Marx 1978b, p. 784). Based on the logic of Mark, it tends to decrease the surplus value (Marx, Simpson, \& Ryazanskaya, 1963). However, the tendency of decreasing interest in a capitalistic society was noticeable in Western society after the Industrial Revolution in the $19^{\text {th }}$ century as well as in the US after the mid-20 $0^{\text {th }}$ century (Medio, 1972; Wolff, 1979). Marx predicted that capitalism essentially reduces the ratio of surplus value, resulting in the panic of the capitalistic society. The surplus value generated from labor is fundamentally converted into capital, and the accumulation of capital reduces the value. Lastly, there has been a financial panic in capitalist society.

Schumpeter significantly dealt with Marx's theory that capital is accumulated through labor. He actively and sharply criticizes the theory (Joseph A Schumpeter, 1942, pp. 9-58). However, he asked, "Can capitalism survive? No. I do not think it can." He also showed his skepticism about the sustainability of the current capitalism (Schumpeter, 1942, p 61). Lastly, it indicates that the rate of increase for the total output will reach a certain limit. Schumpeter admits that the new combination based on the process of creative destruction led by entrepreneurs was not an alternative to the continuous growth of capitalism. He insists that the new combination disappears, and the closed season controlled by big business will emerge. The situation leads to the vanishing of investment opportunity (Schumpeter, 1942, p. 111). However, with the changes in the economic process brought about by innovation, together with all their effects and the response they received from the economic system, Schumpeter designated the term, Economic Evolution (Schumpeter, 1939, p. 83). This type of innovation combines factors in a new way or carries out a new combination. However, the future of economic evolution suggested by Schumpeter is the decomposition of 
capitalism and socialism, set with a model of the Labor Party of the UK (Schumpeter, 1942, p. 167). Marx said that corporation and production cooperatives are "social ownership."

\section{Discussion on growth limits of capitalism in the late $20^{\text {th }}$ century and early $21^{\text {st }}$ century}

Peter Drucker suggested that the knowledge-based society is a society wherein knowledge controls the main area of the society as well as the economy and added that it is a form of a post-capitalist society. First, knowledge brings about industrial revolution integrated with working tools, manufacturing processes, and products. Second, knowledge leads the productivity revolution which significantly improves productivity. Third, knowledge leads the management revolution which is applied to it (Drucker \& Drucker, 1994, p. 46). Drucker identified that even with a three-stage revolution, the existing capitalist society is being changed to a knowledge-based society, which is very different from the capitalist society. As a means of production, the importance of knowledge increases in post-capitalist society. Thus, it is expected that, among the two important means of production in a capitalist society, the traditional role and the function of capital as well as the disappearance of labor will be redefined (Drucker \& Drucker, 1994, p. 115). That is, labor that serves as an asset disappears, and an employees' society in which they serve as the subjects is formed. Furthermore, because the pension fund accounts for a major part of the capital, the prevalence of a capitalist society having no capitalists is increased. Drucker said that the size and sustainability of the productivity of a knowledge-based society depends on the effort to improve the productivity of knowledge and service employees, the improvement of knowledge productivity, the design of an organization based on knowledge, and the reliability of the goal for an individual. The peculiar thing is that Drucker mentioned the necessity of the recovery of government and citizens' function in the sustainability of a knowledge-based society (Drucker \& Drucker, 1994, pp. 236, 251). This point is very similar to the vision of Schumpeter on social democracy. He called the knowledge-based society an entrepreneurial society, led by an innovation agent, who is an entrepreneur, and suggested that the requirement for society to thrive is substantial social innovation (Drucker, 2014, p. 257).

Jeremy Rifkin identified that the world led by the progress of technological innovation is the end of work. For a growing number of working people who find themselves either underemployed or unemployed, the concept of trickle-down technology is of very little solace (Rifkin \& Kruger, 1996, p. 165). He said the characteristics of the new society are the decline of the global labor force, the reduction of the middle class, a new division between high-tech winners and losers, an increasing rate of unemployment, and a more dangerous world. As a result, Ripken predicted that globalizing the social innovation economy would be realized by re-engineering the work week, a new social contract, and empowering the third sector (Rifkin \& Kruger, 1996, p. 275). In this third industrial revolution, the lateral power is the transforming energy, the economy, and the world. Ripken said mutual cooperative, horizontal, and open economic system, which are different from the existing system, would be established, and is being established (Rifkin, 2011, p. 277). That is the sharing economy or the Collaborative Commons, summarized as the zero marginal 
cost society (Rifkin, 2014, p. 7). It refuted the opinion of Hardin that in the end, all commons are destined to collapse head-on. It also completely coincides with that of Rose and Ostrom who once raised the question on the old idea thought by economists for a long time that individuals pursue only their self-interest in a market (Hardin, 1968; Ostrom, 1990; Rose, 1986).

Piketty said the capital-labor split in the $21^{\text {st }}$ century occurs as the ratio of capital continuously increases the dynamics of the capital/income ratio around the world. He said that the acceleration of unequal distribution based on the capital of the capitalism of the $21^{\text {st }}$ century is a global phenomenon and suggested that a viable alternative of capitalism is a social state (Piketty \& Goldhammer, 2014, p. 471). A modern redistribution based on a social state does not include transferring the income from the rich to the poor, at least not in such an explicit way. Instead, it includes financing public services and replacement incomes that are more or less equal for everyone, especially in the areas of health, education, and pensions (Piketty \& Goldhammer, 2014, p. 479). All the rich countries, without exception, faced the $20^{\text {th }}$ century from an equilibrium in which less than a tenth of their national income was consumed by taxes to a new equilibrium in which the figure rose to between a third and a half (Piketty \& Goldhammer, 2014, p. 476). However, it is true that a social state in poor, and emerging countries are different from the rich countries in terms of status or tendency. A nation takes 10-15\% of its national income in Sub-Saharan Africa and South Asia; 15-20 \% in Latin America, North Africa, and China; and about $10 \%$ in India. However, it has been shown that the ratio of a nation's national income decreased or is on the decrease, and the tendency accelerates the inequality between the capital and labor of nations (Piketty \& Goldhammer, 2014, p. 491). Piketty said that overcoming the accumulated inequality of the distribution between capital and labor of capitalism by forming a social state, including a global capital tax, is an alternative to handle the stagnation of economic growth. This is also shown as a worsening of the distribution inequality of capitalism in the $21^{\text {st }}$ century (Piketty, 2010, p. 61).

\section{Discussion on growth limits of capitalism in Korea}

Ha-Sung Chang identified that Korean capitalism is broken because it does not have the three growth elements: employment, wage, and distribution. As an alternative, he suggested righteous capitalism (Ha-Sung 2014 p. 521). For five years from 2008 when the economic crisis occurred until 2013, the average global growth rate of Korea was $1.7 \%$, and the average growth rate of the US and England was $0.8 \%$ and $-0.6 \%$, respectively. The record rates brought about capitalism in crisis. Chang pointed out that the crisis was caused by the structure of inequality and the worsening of inequality rather than by the slowdown of growth, and that the fruit of growth did not have an impact on people's lives (Ha-Sung 2014 p. 20). He said, for the past 30 years when market fundamentalism dominated, the conditions of employment have been aggravated, and unstable employment has increased such occurrences as income inequality, class polarization, an economic growth structure without employment, and an increase in low-wage employees and temporary workers. Korea has experienced the same economic conditions. Ha-Sung Chang analyzed that as corporate income continuously increases against household income among household income, corporate 
income, and government income, which comprise the gross national income, it seems that the internal reserves of listed companies rise without an end, resulting in a lack of corporate investment for job creation, a decrease in consumption in the household section, and the stagnant growth of capitalism in Korea. He takes an optimistic view that the growth limits of capitalism in Korea can be overcome by converting capitalism to righteous capitalism guaranteed by a competing system, fair market, and realization of justice. He also added that the current growth stagnation can be handled. In particular, he identified that based on trust in shareholders, who are the owners of assets in modern capitalism rather than capitalists, if shareholder capitalism in the investment of foreign companies in Korea and even in the state-run firms of state capitalism like in China and Russia is based on competition, fairness, and justice, capitalism, with its growth stopped, will begin again (Ha-Sung 2014 p. 247).

The discussion on partnered growth suggested by the former Prime Minister of Korea Un-Chan Chung and professor Jang-Woo Lee also showed that as the growth of Korean capitalism is halted, it is necessary to have capitalism with partnered growth as an alternative for sustainable growth. This shows that Korean capitalism does not grow, or its growth is significantly stagnated (Jang-Woo Lee, 2011. p. 49; Won-Chan 2013 p. 20). Chung mentioned that if there is strong intention from the government leading the change in large companies and self-help from small- and medium-sized enterprises (SMEs) for partnered growth which is crucial for the new capitalism, the alleviation of polarization, improvement of job stability, and continuous creation of new jobs can be achieved. These three factors should be addressed for capitalism in Korea (Won-Chan 2013 p.226). He said that the key values for partnered growth, including profit sharing, are not applied to companies and the economy but to both the philosophy of life and the value of a new social community (Won-Chan 2013 p. 228, 230). Shared value creation focuses on identifying and expanding the connections between societal and economic progress (Porter \& Kramer, 2011). Shared value as the next evolution in capitalism will not just hold the key value, unlocking the next wave of business innovation and growth, but will also reconnect the success of companies and communities in ways that have been lost in an age of narrow management approaches, short-term thinking, and deepening divides among institutions in society (Porter \& Kramer, 2011). Lee said that the new coexistence of large, small, and medium-sized companies through partnered growth, a rule of the game that has no loser, is a way to build a sustainable economy (Jang-Woo Lee, 2011. p. 15). However, he suggested the corporate ecosystem theory for the theoretical background of partnered growth, which is the basic theory that creates the cooperative system among companies, and the theory of behavioral change for partnered growth to focus on the sustainable development of the Korean economy (Jang-Woo Lee, 2011. p. 111). Thus, Lee also mentioned that partnered growth is necessary to overcome the weakness of the capitalist economic system, but his view is different from those of Porter or Un-Chan Chung who said that partnered growth is an alternative to overcome the growth limits of the existing capitalism. In an era when great ideas can sprout from any corner of the world and IT has dramatically reduced the cost of accessing them, it is now conventional wisdom that virtually, no company should innovate on its own (Pisano \& Verganti, 2008). In this regard, Lee insisted that partnered growth is essential for the survival and development of large companies as well as start-ups and SMEs (Jang-Woo Lee, 2011, p. 190). 


\section{Model building to conquer the growth limit of capitalism Model building: open innovation economic system}

The Open Innovation Economic system (OIES) is a macroscopic economic system wherein a sub economic system based on open innovation led by start-ups and small and medium enterprises (SMEs), a sub economic system based on closed innovation led by big businesses, and a sub economic system based on social innovation economy led by social enterprises or independent third sectors are interconnected, thereby affecting each other. OIES basically targets the economic system of one nation. However, the concept of the same macroeconomic system could be applied to a global and regional economic system.

That is, the capitalist economic system in a modern society is composed of the three sub economic systems described in Fig. 1 regardless of the characteristics of the political system of the economic system. An open innovation economy indicates an economy based on SMEs or start-ups led by individual entrepreneurs. It features a new combination between technology and the market suggested by Schumpeter (Brunswicker \& van de Vrande, 2014; Schumpeter, 1934, pp. 15, 65). Open innovation economy is characterized in such a way that the original producer of technology, which is emerging under a knowledge based development as a new economic culture, is not the same as the subject delivering the production to a market (Carrillo 2015, Chesbrough, 2003, p. 43). Thus, the open business model, which is a new combination between technology and a market and led by various entrepreneurs, defines the growth and development of an open innovation economy (Chesbrough, 2007, 2010; 2013, p. 2). A closed innovation economy is led by mainly big businesses wherein monopolistic practices are dominant, and investment opportunities no longer exist (Schumpeter, 1942, pp. 81, 87). In this case, large companies create their own value based on the technology they have accumulated internally and transfer it to a market. Thus, they lead the closed innovation economy (Chesbrough, 2003, pp. 2124). Social innovation economy indicates that in the economy, specific technology or knowledge creates a social value that meets social requirements without the intermediation of the market and provides it to the society (Rifkin \& Kruger, 1996). Social innovation refers to innovative activities and services that are motivated by the goal of meeting a social need and that are predominantly diffused through organizations whose primary purposes are social (Mulgan, 2006). The so-called sharing economy such as Aribbnb, or Uber, and collaborative economy such as open source communities are concrete examples of social innovation economy which connects new technology and social

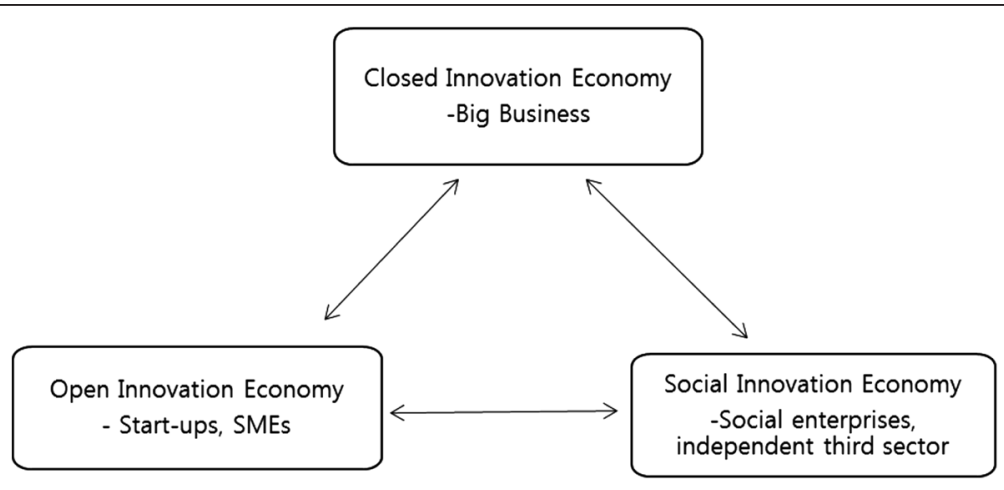

Fig. 1 Components and structure of an open innovation economic system 
requirement (Belk, 2014; Kostakis \& Bauwens, 2014; Zervas, Proserpio, \& Byers, 2014). Social enterprises that comprise the social innovation economy access the Internet of the things through a plug. They also play and use open and distributed architecture to create peer-to-peer horizontal collaborative commons (Rifkin, 2014, p. 109; Zervas, Proserpio, \& Byers, 2014). With the activation of the Internet of the Things, including the communication Internet, logistics Internet, and energy Internet, productivity significantly increases, and a zero-marginal-cost society is realized. Thus, it is expected to implement a sharing economy that reorganizes most parts, such as energy, residence, and automobile logistics, based on access from ownership (Rifkin, 2014, p. 389; Sundararajan, 2013; Weitzman, 1985).

However, for OIES, the dynamics of the three sub economic systems are cyclical shown in Fig. 2. An economic system in which the dynamics of OIES actively occur can evolve and continuously create new jobs without the stagnation of growth. Thus, the growth limits of capitalism can be overcome when the dynamics of OIES actively occur based on the interconnection between the three sub economic systems. In this case, first, creative start-ups and SMEs of the open innovation economy are provided to the closed innovation economy in open and innovative ways like $\mathrm{M} \& \mathrm{~A}$, technology licensing, or open platform so that big businesses can continuously perform new combinations in a short period for continuous job creation. Second, virtuous big businesses of the closed innovation economy distribute wages and take on a sufficient tax burden through large scale employment. They continuously support the social innovation economy in an indirect way through this or in a direct way through voluntary contributions. Third, the social innovation economy plays a decisive role in the formation and development of a market by nurturing the social enterprises and social values created through the creative and newly open combination between technology and society. That is, social innovation economy actively provides the seed for open innovation which is a new combination between creative technology and the market in the dynamics of OIES.

\section{Interactive relations in OIES}

Companies in the open innovation economy are transferred to the closed innovation economy through mergers and acquisitions (M\&A), and they get the opportunity to

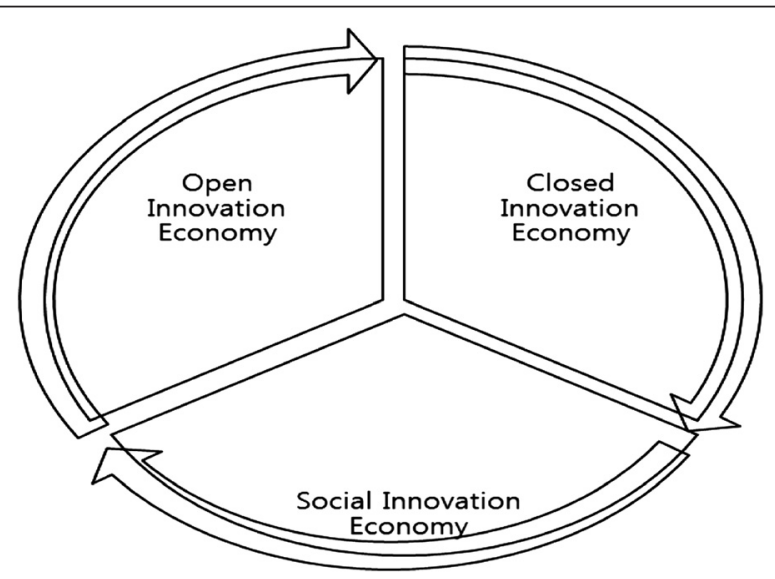

Fig. 2 Dynamics of an open innovation economy system 
mass-produce new business models for a short period. In not product but also service industries, open innovation based on customers, platform, R\&D centers, or others are popular in SMEs, start-ups, or even Multinational enterprises (MNEs) right now (Della Corte, Iavazzi,\& D’Andrea, 2015; Han \& Cho, 2015; Patra \& Krishna, 2015). In open Innovation economy, diverse and heterogeneous technologies or expectations can lead to new creative combination between technology, and market which is the source of interaction with closed innovation economy (Lee and Lee, 2015). Nowadays, innovative city itself becomes the open innovation platform at which interactions between SMEs or Start-ups, and big businesses are increasing (Inkinen, 2015; Pancholi, Yigitcanlar, \& Guaralda, 2015). Large companies of the closed innovation economy can easily and rapidly perform a new combination between technology and market through corporate venture capital $(\mathrm{CVC})$ investment. Various virtuous interconnected relations, including the M\&A in Fig. 3, are important factors for the activation of the dynamics of an open innovation economic system. For example, Apple bought about 20 technical companies related to smartphones through M\&A, and opened the App Store to have a partnership with many SMEs around the world to enter into the smartphone industry for a short time and created millions of employment opportunities. Google also entered into the smartphone industry for a short time period through M\&A with about 10 SMEs and start-ups like Android OS companies to create more new jobs around the world, specifically in the US. IBM changed itself as a software company from a manufacturing company through positive M\&A with promising SMEs and start-ups. It achieved a new combination between technology and market, which is different from the existing computer industry, and created new jobs that replace the presently declining industry. SMEs and the large companies of Silicon Valley in the US that joined the Corporate Business Model Innovation Program of UC Berkeley confirmed the pursuit of mutual interests based on virtuous interactive relations described in Fig. 3. Large multinational corporations (MNCs) of the closed innovation economy basically apply various open innovation strategies for relations between SMEs and start-ups (Mortara \& Minshall, 2014).

The closed innovation economy and the social innovation economy described in Fig. 4 are the core of corporate social responsibility (CSR). In particular, in terms of the relations between a big business and a local society as well as between a big business and a government, large companies should consider social and environmental interests and voluntarily cooperate with stakeholders for their sustainable survival (Crowther \& Aras, 2008; Jones 1980). Big businesses of the closed innovation economy directly and indirectly support the social innovation economy. Through this process, a big business

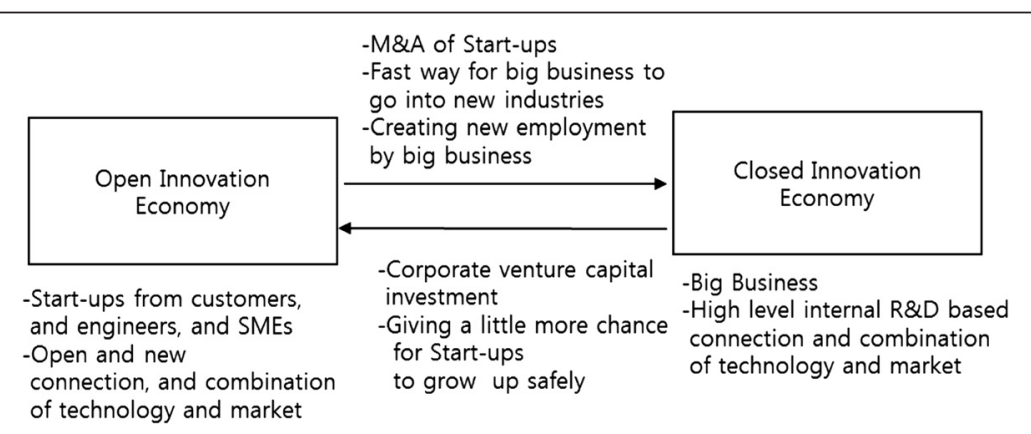

Fig. 3 Concrete relationship between the open innovation economy and closed innovation economy 


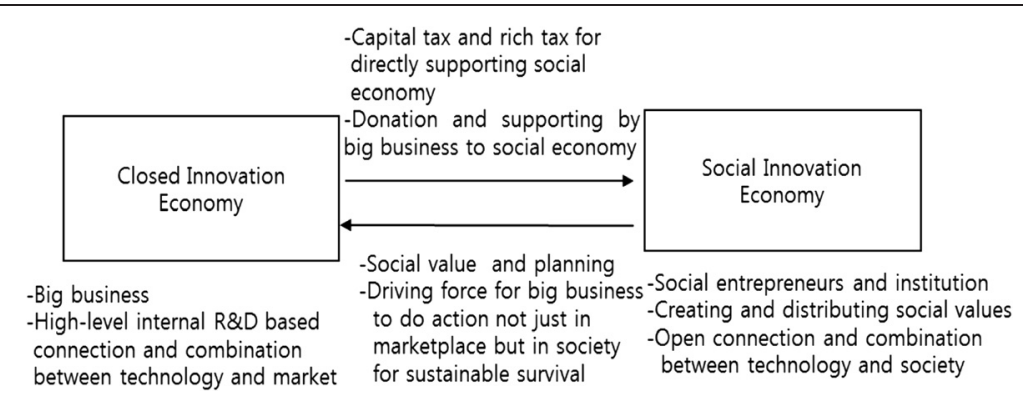

Fig. 4 Concrete relation between the closed innovation economy and the social innovation economy

directly gets a social reputation, which is essential for its long-term survival and indirectly benefits from the final marketization of the value created in an open innovation economy by social enterprise. Increase of brand value of big business give positive effect for big business to support social innovation directly (Lee \& Workman, 2015). The relation described in Fig. 4 gives the direct benefit of securing potential customers to large companies and contributes to various and continuous production of social value in a social innovation economy. In addition, it continuously allows new combinations between technology and market, which are essential for the survival of large companies. The increasing number of companies known for their hard-nosed approach to businesses, such as Google, IBM, Intel, Johnson \& Johnson, Nestle, Unilever, and Walmart, have begun to embark on important shared value initiatives (Porter \& Kramer, 2011). The simple macroeconomics of profit-sharing possesses natural immunity to stagnation (Weitzman, 1985) (Fig. 5). Green economy can become the interaction between Closed Innovation sub economy and Social Innovation sub economy (Cooke, 2015).

In a social innovation economy, social enterprises create social values by combining technology, and society, which becomes a source of new combination between creative technology and the market. Social innovation is normally based on social responsibility, social capital, or social entrepreneurship (Kim \& Jung, 2015). But, open social innovation functionally can be defined as open combination between technology and society. Open Social Innovation (OSI) is the application of either inbound or outbound open innovation strategies, along with innovations in the associated business model of the organization, to social challenges (Chesbrough \& Di Minin 2014). Meanwhile, many SMEs and start-ups of the open innovation economy try to join the social innovation economy with their experience and know-how and become a major supply source of knowledge, know-how, and

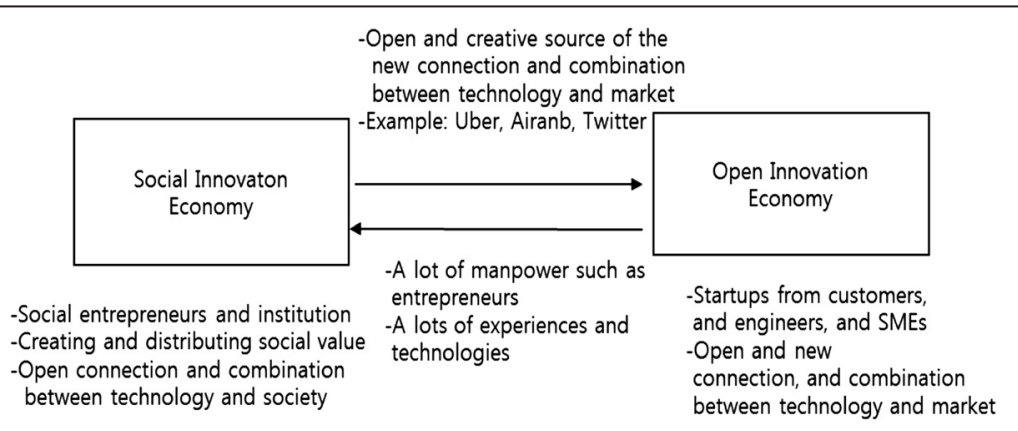

Fig. 5 Concrete relation between social innovation economy and open innovation economy 
manpower for the social innovation economy. In the open innovation economy, the creative source of new or shifting start-ups through the new combination between technology and the market is based on the social innovation economy. The increased web accessibility of social innovation sub economy has motivated the interaction between theses 2 sub economies (Noh, Jeong, You, Moon, \& Kang, 2015). In addition, even if the social innovation economy is financially supported by the closed economy, the actual manpower, know-how, and experience are supported from the open innovation economy. The case of the $8^{\text {th }} \mathrm{Na}$ tional Biennial Grassroots Innovation Awards of India, which was identified through participant observation, is exactly similar. All 41 winners, including the three student award winners, were supported with manpower, patent application, product development, and market sales know-how beyond the social type from the open innovation economy, such as the honey Bee Network. They were also financially supported from the closed innovation economy like the National Innovation Foundation of India. This action has vitalized the social innovation economy. If both economies configure the innovation community with a flat and open collaboration network, the most active collaboration can be realized. In the case of India, the role is played by the Honey Bee Network (Pisano \& Verganti, 2008). The interaction between Social Innovation sub economy and Open Innovation sub economy will be activated by the increased chances of demand articulation in open social innovation (Kodama \& Shibata, 2015). For example RFID which had been used at defense, security, environmental applications, is moving to market area such as transportation, healthcare, agriculture through demand articulation (Jung \& Lee, 2015).

\section{Theoretical roots of OIES}

First, the theoretical reason for the relation among the open innovation economy, its closed innovation, and the social innovation economy can be found in the innovation and economy development through the new combinations of Schumpeter as well as in the open innovation for the open connection between technology and the market and the open business model for the open combination of Chesbrough. To produce other things or the same things using a different method means to combine these materials and forces in various ways. This is called a "new combination" (Schumpeter, 1934, p. 65). Innovation combines factors in a new way or carries out new combinations (Schumpeter, 1939, p.84). In addition to this, entrepreneurs carry out innovations (Schumpeter, 1939, p.100). Open innovation means that valuable ideas can come to a company and the market both internally or externally (Chesbrough, 2003, p. 43). In addition, a business model serves as an intermediate construct that links those technical and economic domains (Chesbrough, 2003, p. 69). The knowledge economy, the open connection in an open innovation and the open combination in the open business model of technology and market, is the driving force of new start-ups and creative value creation (Chesbrough, 2010).

Second, the theoretical framework of big businesses based on the closed innovation economy is Schumpeter's Monopolistic Practices, Closed Season, and Corporate Social Responsibility, as well as the theory of partnered growth of Un-Chan Chung and Jang-Woo Lee. If big businesses continuously pursue monopolistic behaviors and closed strategies, investment opportunities will vanish (Schumpeter, 1942, pp. 87, 111). In addition, if large companies directly and indirectly support the social innovation economy and creating shared value (CSV), it is essential to guarantee corporate social responsibility (CSR) for long-term survival (Holme \& Watts, 1999; Porter \& Kramer, 2011). The theory 
of partnered growth, which handles the win-win growth strategy and partnered growth between SMEs that represents the open innovation economy and big businesses that represent the closed innovation economy, also serve as the theoretical basis for a mutual, virtuous, cyclical relation between the open innovation economy and the closed innovation economy (Won-Chan 2013, p. 226; Jang-Woo Lee, 2011, p.15).

Third, the theoretical basis of social innovation economy is Schumpeter's Socialist Blueprint, Ostrom's Governing the Commons and Sharing Economy or CSV. Socialist management would be able to start from a system of values that have evolved because of their capitalist predecessors (Schumpeter, 1942, p. 172). With the development of the Internet, marginal cost approaches zero, and the sharing social innovation economy emerges in automobiles, homes, and energy fields. The social blueprint of Schumpeter is partially being realized. Lastly, the shared economy offers a happier life, more money, more flexible lifestyle, reduced reliance on debt, and more trust in strangers as the subjects of the sharing economy that creates sharable value to essentially give benefits to them (Benkler, 2004). According to Ostrom, common pool resources (CPR) could be managed successfully without falling as prey to the "tragedy of the commons" through the design of durable, cooperative institutions that are organized and governed by the resource users (Ostrom, 1990, p. 25). Social open innovation based on the open combination between technology and society receives direct and indirect support from big businesses based on CSR and CSV. In addition, the interaction between the social innovation economy and open innovation is actually based on CSV.

Fourth, the dynamics of OIES has various theoretical bases. 1.) The theoretical base of the dynamics of OIES comes from Schumpeter. The dynamics of OIES basically complements the one-way, three-step discussion on dynamics like Schumpeter's individual entrepreneur based new combination, big businesses based monopolistic practices, and socialist blueprint based on socialist democracy by changing it to simultaneous and feedback loop-style dynamics (Schumpeter, 1934, p. 59; 1939, p. 65-106; 1942, p. 87, 172, 232). 2.) Simon's bounded rationality defines organizational learning beyond personal recognition and offers a theoretical basis for the dynamics of OIES as well as his organizational dynamics (Simon, 1982; Simon, 1991). 3.) The discussion on dynamics capability in a company suggested by Teece is the basis of the dynamics of OIES centered on the learning dynamics at the basic organizational level (Teece, Pisano, \& Shuen, 1997). 4.) Christensen's discussion to find the industrial dynamics based on the viewpoint of open innovation and Kong Rae Lee's research inquiring about the innovation dynamics of the Japanese machine tools industry with users collectively forming the theoretical basis of OIES dynamics because they analyzed open innovation based on economic dynamics (K. R. Lee, 1996). Industrial dynamics must increasingly be conceived in terms of convergence and divergence rather than industry-bounded trajectories by open and industry-transcending patterns of innovations (Christensen, 2014; Christensen, Olesen, \& Kjær, 2005). 5.) Linsu Kim's theory, which suggests organizational learning through catch-up growth and the dynamics of Korea's technological learning through innovative imitation, is also an important theoretical basis of the dynamics of OIES (Kim, 1997, 1998). 6.) Keun Lee's and Chaisung Lim's discussion on the learning and dynamics of Korean industry through catch-up is the basis of the dynamics of open innovation (K. Lee \& Lim, 2001). They introduce the external base by adding knowledge-based learning and industrial dynamics through catch-up growth with an 
internal base and by explicitly applying the open innovation-based industrial dynamics to the catch-up model. For the effect of open innovation policy on the National Innovation System (NIS), the inquiry about the dynamics of open innovation at the national level through system dynamics is also matched with the theory of the dynamics of OIES (Yun, Won, Hwang, Kang, \& Kim, 2015).

\section{Simulation of the dynamics of OIES}

\section{Natural life cycle of OIES dynamics in a knowledge-based economy}

In the $21^{\text {st }}$ century, knowledge-based economies or knowledge-based societies in which knowledge production and distribution are activated around the world and knowledge and technology become a major deciding factor are already established as dominant characteristics (Burton-Jones, 2001; Foray \& Lundvall, 1998). OIES dynamics and a knowledge-based economy can be simulated through a mental experiment shown in Fig. 6.

That is, if the ratio of the social innovation economy is $100 \%$, the ratio of the open innovation economy grows in the early stage. Then, the closed innovation economy, based on big businesses, develops. However, as OIES dynamics evolve, the ratio of the open innovation economy significantly exceeds the majority of the social innovation economy.

In addition, in the middle stage, the open innovation economy becomes the largest portion, followed by the social innovation economy and closed innovation economy. The open innovation economy actively operates, and the social innovation economy continuously decreases. The closed innovation economy, based on big businesses, slowly increases. The OIES dynamics in the middle stage accelerates to increase the speed of economic growth and employment.

If the OIES dynamics mature when social agreement and government intervention are weak, the economy, which is led by the closed economy based on big business like the example in Fig. 6, is established. In addition, the ratio of the social innovation economy decreases, greatly lower than the majority, and that of the open innovation economy also decreases to the majority or lower than that of the majority. The maturity led by the closed innovation economy restricts new employment because of limited new combination. The ratio of the open innovation economy and social innovation economy, leading the largest portion of job creation, significantly decreases, thereby resulting in a high unemployment rate. By any chance, if the economic growth, led by the closed innovation economy, lasts for a certain period, the growth continues without employment.

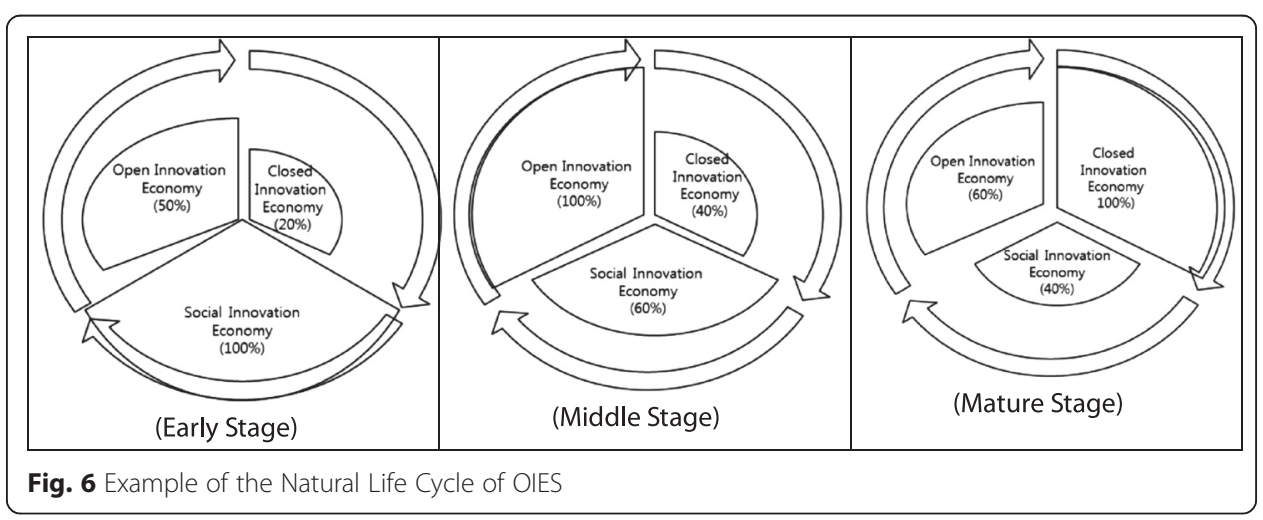




\section{Low-speed and high-speed example of OIES dynamics}

The low speed of the dynamics of OIES as well as the economic growth and high unemployment rate are shown in (a) and (b) of Fig. 7. In the case of (a), there is a strong open innovation ecosystem based in SMEs as well as a sound and sizable closed innovation economy but a weak social innovation economy. Because of this, the growth stagnates. In this case, the financial support to the social innovation economy of big businesses is weak, and the support to the social innovation economy becomes insufficient in terms of experience, know-how, and manpower from the open innovation economy. The subjects of the open innovation economy focus on limited open innovation that the combination of the current technology and market is newly improved rather than the creation of new jobs through creative and new start-ups based on the seed grown in the social innovation economy. In addition, there are not enough open innovation relationships between the open innovation economy and the closed innovation economy. The closed innovation economy based on big business also creates new source technology inside and focuses the activity to deliver the technology to the existing or expanding market, resulting in a more aggravated situation of no additional job creation. Japan and Germany have an economic system that is closer this. Without the efforts of vitalizing the social innovation economy and, an open innovation strategy based the relation between the open innovation economy and the closed innovation economy, it is inevitable that this economic system promotes growth without job creation resulting in growth stagnation.

In the case of (b), big businesses sustain closed innovation-based growth without a socialcontract or national intervention, and SMEs as well as start-ups that are competing in an open innovation economy are depleted. Of course, the social innovation economy

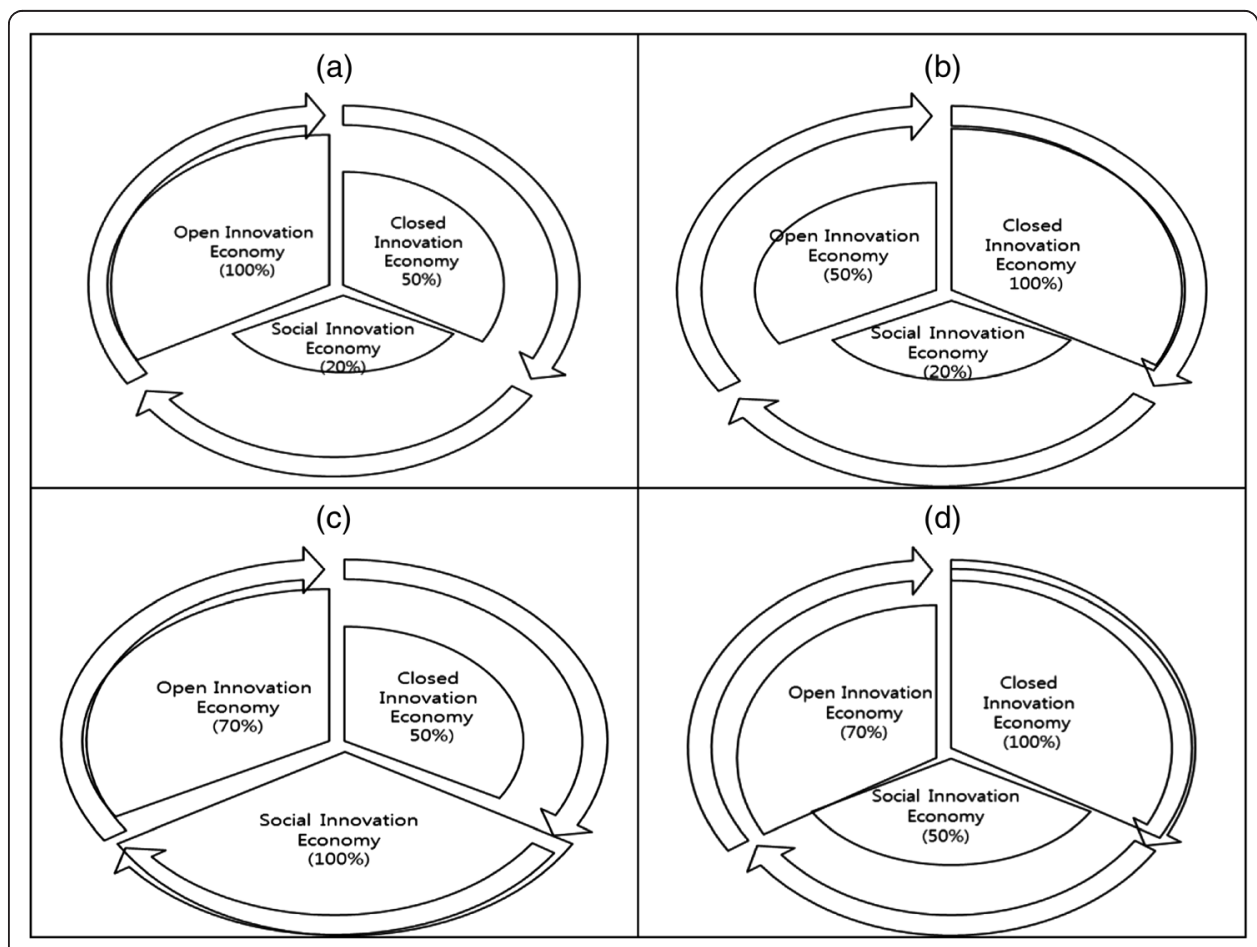

Fig. 7 Examples of Low-speed OIES Dynamics and High-speed OIES Dynamics 
with slight direct and indirect support, in the good will of the closed innovation economy, is more contracted to a size that decreased during the OIES dynamics procedure. In this case, big businesses do not prefer the cooperation method with SMEs or start-ups through open innovation strategies like friendly $M$ \&A, partnerships, and technology licensing based on its strong market share and capital power. In the case of (a), economic growth stagnates because it is led by big businesses, and even if economic growth is fast because of environmental factors, it leads to growth without employment and stops the economic growth. This is the OIES dynamics that are closest to the conditions of the current Korean economy. The economies of most European nations, except for Germany, apply to this case.

It is of note that the common point of the two case models in which the dynamics of OIES are weak is a weak social innovation economy. The social innovation economy is a necessary condition that determines the vitality of the dynamics of OIES.

The fast speed of the dynamics of OIES, low unemployment, and rapid speed of economic growth are shown in (c) and (d) of Fig. 7. In the case of (c), social enterprises and new social entrepreneurs in a sizeable and strong social innovation economy actively combine technology and society in various ways. For this, massive support from the government and strong financial support of large companies supported or built by the government are established. In addition, in an open innovation economy, manpower and know-how are massively provided to activate the social innovation economy and convert a new combination between technology and society to a new combination between technology and the market to establish the foundation of startups for the open innovation economy. Exemplary nations at an early stage of economic development apply to this case. Up to know, China's economy has only closely resembled this case, although now, India's economy also applies to this case. The Indian government has made efforts to strengthen the open innovation economy, vitalize the social innovation economy, financially support the social innovation economy, and promote the growth of big business at a certain scale by linking the open innovation economy and the social innovation economy through the Grass Roots Innovation Awards, Innovation Festival of India, and Innovation Foundation of India, respectively. Korea's rapid economic growth from the 1960s to the 1980s also applied to this case.

In case of (d), this economic system is formed through a social contract or a strong government intervention when the growth of the OIES dynamics is stagnated. Mutual development with SMEs or start-ups is pursued through strong regulation by the government on the closed innovation system and on open innovation strategies like friendly M\&A, partnership, and technology licensing. For example, the US continuously implements and develops the world's first and top regulation system on big businesses of the closed innovation economy, such as stipulating unfair businesses to be unlawful and allowing people take legal actions through the Sherman Act of 1890, Clayton Act of 1914, Hart-Scott-Rodino Act of 1976, and the Federal Trade Commission. In addition, big businesses directly provide financial support or the nation activates various types of social economies by using taxes. Then, a social innovation economy continuously creates jobs in all economic systems. In the short term, it becomes the source of a new combination between the technology and the market of SMEs and start-ups. In the long term, it becomes the seed of continuous new combinations of big 
businesses. In the US, the image of the best big companies set by Rockefeller, Carnegie, etc., in the 1910s has led to continuous contributions and financial support of big businesses to the social innovation economy. The economic systems of the US and European countries from the 1970s to the 1980s, enjoying rapid economic growth, belong to this case. The economy of the US with a high economic growth of $4 \%$ and little promotion of job creation as of late 2014 is similar to this case. President Obama suggested the "Startup America Partnership" program to lead the mutual virtuous circle between large companies and SMEs, and the ratio of the open innovation economy against the closed innovation economy would increase. Then, its economic growth rate rises.

\section{Discussion and conclusion}

\section{Discussion}

It is clear that the dynamics of OIES have theoretical and practical implications by comparing them with the dynamics of economic evolution and development discussed by Schumpeter.

Even though Schumpeter did not concretely mention technology and market, he is the first scholar who clearly suggested economic evolution and dynamics explaining that the new combination between technology and the market promotes innovation, creates new jobs, and develops the economy (Schumpeter, 1934, p. 15). However, the economic evolution or development discussed by Schumpeter is unilinear. Schumpeter separates the subject that leads to the new combination of the first stage from capital class and defines it as an entrepreneur.

Schumpeter suggested that the subject of economic evolution and the development of the second stage is big businesses. A big business pursues the rate of increase of total output, creates new combination through massive investment in research and development, and leads the process of creative destruction (Schumpeter, 1942, p. 81). However, the big business-based economy goes through monopolistic practices, closed season, and the disappearance of investment opportunities.

As an alternative to overcome the limits of the second stage, Schumpeter showed socialist blueprints that focus on the civilization of capitalism and provided the Labor Party in the United Kingdom (UK) as an example.

The three stages of the economy development logic of Schumpeter are generally accepted as the types of sub economies in the dynamics of OIES. The unilinear economic development of Schumpeter had been practically complemented based on the practical experience in economic development and the academic performance accumulated for the past 65 years after the death of Schumpeter. After this, the dynamics of OIES were created.

All capitalist economic systems have a development stage identical with the economic development stage model of Schumpeter. However, the reasons that the current situation is different from the final expectation of Schumpeter and that the economic development speed and employment of capitalistic economic systems are different can be gleaned from the fact that economic development in three stages is performed by the stages and overlap. These overlapped economic development dynamics are shown in various ways in accordance with each economic situation or with internal and external conditions. 
Therefore, in the dynamic of OIES, the distinction between low and high dynamics is not absolute. The models and practical cases shown in the simulation are just a few examples. However, it is essential to introduce a new combination between technology and the market for creative and new emergence of SMEs and start-ups and a new combination between technology and society for creative social enterprise and social innovation economy development, as well as a proper open innovation strategy to maintain the virtuous cyclic relation between the closed innovation economy and the open innovation economy as well as with the social innovation economy, and to sustain a creative and new combination.

\section{Implication and future research topics}

General conditions to invigorate the dynamics of OIES, the key of this research, are divided into five items. First, the new combination between technology and the market should be activated to encourage the emergence of new creative SMEs and start-ups. Second, big businesses should continuously make efforts to introduce new business models and create new jobs by creating new combinations for a short period through friendly M\&A, partnerships, and technology licensing with SMEs and start-ups rather than just focusing on its internal R \& D. Third, big businesses should make an active contribution to vitalize the social innovation economy through direct donations as well as indirectly through the payment of sufficient taxes for creative new combinations between technology and the market for a long time. Fourth, the social innovation economy should actively create creative social values that are necessary for society through the social open innovation of new combinations between technology and society, instead of just focusing on the production of social values. Because of the third industrial revolution that is mainly based on the Internet, various shared values based on zero marginal cost sharply increase, and the importance of social innovation economy rises. Fifth, SMEs and start-ups should actively provide manpower, technology, knowledge, and experience to the social innovation economy based on their expertise in creating a new combination because that is the source of creative new combinations between technology and the market.

Because this research was conducted to develop an economic model to overcome the growth limits of capitalism, it has many limitations and follow-up research projects. First, a global comparative study of the dynamics of OIES is necessary. Through these related studies, concrete and practical cases of high- and low-level dynamics can be accumulated. In addition, the composition of the three types of sub economies of high- and low-level dynamics and cases of interaction among them can be accumulated. As such, this research proposes a research program called the "Global Research Program" to analyze the differences between high and low dynamics of OIES in the OECD or UN.

Second, to thoroughly define the dynamics of OIES, multidisciplinary cooperative research in economics, business administration, sociology, politics, engineering, law, etc., should be conducted. For this, first, a "Global Research Network" for research collaboration on the dynamics of OIES should be established. The construction of a research network should cover the Society of Open Innovation: Technology, Market, and Complexity or the Global Open Innovation Forum, an interdisciplinary cooperative research should be activated to define the dynamics of OIES in depth and in multidisciplinary 
ways. In addition, an academic platform is necessary to accumulate and develop the performance of the cooperative research on the dynamics of OIES. At present, there are journals like the Journal of Open Innovation: Technology, Market, and Complexity; Journal of Evolutionary Economics; System Dynamics Review, etc. to systematically accumulate the performance of multidisciplinary research. Existing journals and new ones should be supported. In addition to theses, there are a lots of research topics such as finding out concrete technology which evolve in OIES dynamics, or active interaction conditions between sub economies which motive dynamics of OIES.

If we add concrete research topics from this study, they are as follows. First, statistical analysis of open innovation and firms' performance of SMEs after big business increases at any NIS, will show concrete evidence of Schumpeterian dynamics. Second, system dynamics modeling of Schumpeterian dynamics and simulation of several conditions will give us a chance to develop Schumpeterian dynamics and new strategy or policy implication in any special situation. Third, case study of firms in social innovation economy can give us to understand a little more details about the relationships between Closed Innovation sub economy and Social Innovation sub economy, and between Social Innovation sub economy, and Open Innovation sub economy.

Received: 23 April 2015 Accepted: 26 October 2015

Published online: 10 November 2015

\section{References}

Belk R. You are what you can access: Sharing and collaborative consumption online. J Bus Res. 2014;67(8):1595-600. Benkler Y. Sharing nicely: On shareable goods and the emergence of sharing as a modality of economic production. Yale Law J. 2004;114:273-358.

Brunswicker $\mathrm{S}$, van de Vrande V. Exploring open innovation in small- and medium-sized enterprises. In: Chesbrough $\mathrm{H}$, Vanhaverbeke W, West J, editors. New frontiers in open innovation. Oxford: Oxford University Press; 2014. p. 135.

Burton-Jones A. Knowledge capitalism: Business, work, and learning in the new economy. Oxford: Oxford University Press; 2001

Carrillo FJ. Knowledge-based development as a new economic culture. Journal of Open Innovation: Technology, Market, and Complexity, 2015;1(1):15.

Chang H-J. Kicking away the ladder: Development strategy in historical perspective. New York: Anthem Press; 2002.

Chang H. 23 things they don't tell you about capitalism. New York: Bloomsbury Publishing; 2010.

Chesbrough HW. Open innovation: The new imperative for creating and profiting from technology. Massachusetts: Harvard Business Press; 2003

Chesbrough HW. Business model innovation: It's not just about technology anymore. Strat Leader. 2007;35(6):12-7.

Chesbrough HW. Business model innovation: Opportunities and barriers. Long Range Plann. 2010;43(2):354-63.

Chesbrough HW. Open business models: How to thrive in the new innovation landscape. Massachusetts: Harvard Business Press; 2013

Chesbrough HW, Di Minin A. Open social innovation. In: Chesbrough H, Vanhaverbeke W, West J, editors. New frontiers in open innovation. Oxford: Oxford University Press; 2014. p. 223.

Christensen JF. Open innovation and industrial dynamics - Towards a framework of business convergence. In: Chesbrough H, Vanhaverbeke W, West J, editors. New frontiers in open innovation. Oxford: Oxford University Press; 2014. p. 94

Christensen JF, Olesen MH, Kjær JS. The industrial dynamics of open innovation-Evidence from the transformation of consumer electronics. Res Pol. 2005;34(10):1533-49.

Cooke P. Green governance and green clusters: regional \& national policies for the climate change challenge of Central \& Eastern Europe. Journal of Open Innovation: Technology, Market, and Complexity, 2015;1(1):1-17.

Crowther, D, \& Aras, G. Corporate social responsibility. E-book. Bookboon. 2008. http://bookboon.com/en/definingcorporate-social-responsibility-ebook. (2015.03.14)

Della Corte V, lavazzi A, \& D'Andrea C. Customer involvement through social media: the cases of some telecommunication firms. Journal of Open Innovation: Technology, Market, and Complexity, 2015;1(1):1-10.

Drucker PF. The post-capitalism. New York: Harper and Row Publishers; 1993.

Drucker PF. Post-capitalist society. London: Routledge; 1994.

Drucker PF. Innovation and entrepreneurship. London: Routledge; 2014.

Foray D, Lundvall B. The knowledge-based economy: From the economics of knowledge to the learning economy. In: Need, Siesfeld GA, Cefola J, editors. The economic impact of knowledge. Paris: OECD; 1998. p. 115-21.

Han J, \& Cho, O. Platform business Eco-model evolution: case study on KakaoTalk in Korea. Journal of Open Innovation: Technology, Market, and Complexity, 2015;1(1):1-14

Hardin G. The tragedy of the commons. Science. 1968;162(3859):1243-8.

Ha-Sung J. Korea Capitalism: Over Economy Democratizing to Righteous Economy. Seoul: Heybooks; 2014.

Holme R, Watts P. Corporate social responsibility. Geneva: World Business Council for Sustainable Development; 1999. 
Inkinen T. Reflections on the innovative city: examining three innovative locations in a knowledge bases framework. Journal of Open Innovation: Technology, Market, and Complexity, 2015;1(1):1-23.

Jones, TM. Corporate social responsibility. Calif Manage Rev. 1980; 22(2)

Jung, K, \& Lee, S. A systematic review of RFID applications and diffusion: key areas and public policy issues. Journal of Open Innovation: Technology, Market, and Complexity, 2015;1(1):1-19.

Keynes JM. General theory of employment, interest, and money. New Delhi: Atlantic Publishers \& Distributors: 1935.

Kim L. Imitation to innovation: The dynamics of Korea's technological learning. Massachusetts: Harvard Business Press; 1997.

Kim L. Crisis construction and organizational learning: Capability building in catching-up at Hyundai Motor. Organ Sci. 1998;9(4):506-21.

Kodama, F, \& Shibata, T. Demand articulation in the open-innovation paradigm. Journal of Open Innovation: Technology, Market, and Complexity, 2015;1(1):1-21.

Kostakis V, Bauwens M. Network society and future scenarios for a collaborative economy: Palgrave Macmillan. 2014. Kim, J-h, \& Jung, S-h. Study on CEO characteristics for management of public art performance centers. Journal of Open Innovation: Technology, Market, and Complexity, 2015;1(1):1-21.

Lee KR. The role of user firms in the innovation of machine tools: The Japanese case. Res Pol. 1996;25(4):491-507.

Lee Jang-Woo. Coupled Growth = Win-win growth: Game rule without loser. Future M\&B. 2011

Lee K, Lim C. Technological regimes, catching-up, and leapfrogging: Findings from the Korean industries. Res Pol. 2001;30(3):459-83.

Lee, S, \& Lee, K. Heterogeneous expectations leading to bubbles and crashes in asset markets: tipping point, herding behavior and group effect in an agent-based model. Journal of Open Innovation: Technology, Market, and Complexity, 2015;1(1):1-13.

Lee, S-H, \& Workman, JE. Compulsive buying and branding phenomena. Journal of Open Innovation: Technology, Market, and Complexity, 2015;1(1):1-12.

Marx K. Capital, vol. 1. London: Penguin; 1867.

Marx K. Capital, vol. 2. London: Penguin; 1978a.

Marx K. Capital, vol. 1: A critique of political economy. London: Penguin; 1978b.

Marx K, Simpson R, Ryazanskaya SW. Theories of surplus-value, vol. 1. Moscow: Foreign Languages Publishing House; 1963.

Medio A. Profits and surplus-value: Appearance and reality in capitalist production. In: Hunt EK, Schwartz J, editors. A critique of economic theory. London: Penguin; 1972. p. 312-46.

Mortara L, Minshall T. Patterns of implementation of Ol in MNCs. In: Chesbrough H, Vanhaverbeke W, West J, editors. New frontiers in open innovation. Oxford: Oxford University Press; 2014. p. 223.

Mulgan G. The process of social innovation. Innovations. 2006;1(2):145-62.

Noh, K-R, Jeong, E-S, You, Y-B, Moon, S-J, \& Kang, M-B. A study on the current status and strategies for improvement of web accessibility compliance of public institutions. Journal of Open Innovation: Technology, Market, and Complexity, 2015;1(1):1-17.

Ostrom E. Governing the commons: The evolution of institutions for collective action. London: Cambridge University Press; 1990.

Pancholi, S, Yigitcanlar, T, \& Guaralda, M. Public space design of knowledge and innovation spaces: learnings from Kelvin Grove Urban Village, Brisbane. Journal of Open Innlnnovation: Technology, Market, and Complexity, 2015;1(1):1-17.

Patra, SK, \& Krishna, W. Globalization of R\&D and open innovation: linkages of foreign R\&D centers in India. Journal of Open Innovation: Technology, Market, and Complexity, 2015;1(1):1-24.

Piketty T. L'économie des inégalités. Paris: La Découverte; 2010.

Piketty T. Capital in the $21^{\text {st }}$ century. London: Harvard University Press; 2014.

Piketty T, Goldhammer A. Capital in the twenty-first century. London: Belknap; 2014.

Pisano GP, Verganti R. Which kind of collaboration is right for you? Harv Bus Rev. 2008;86(12):78-86.

Porter ME, Kramer MR. Creating shared value. Harv Bus Rev. 2011;89(1/2):62-77.

Ranis G, Fei JC. A theory of economic development. Am Econ Rev. 1961;51(4):533-65.

Rifkin J. The third industrial revolution: How lateral power is transforming energy, the economy, and the world. London: Macmillan; 2011.

Rifkin J. The zero marginal cost society: The Internet of things, the collaborative commons, and the eclipse of capitalism. London: Macmillan; 2014.

Rifkin J, Kruger E. The end of work. Winnipeg: Social Planning Council of Winnipeg; 1996.

Rose C. The comedy of the commons: Custom, commerce, and inherently public property. Univ Chicago Law Rev. 1986;53(3):711-81.

Schumpeter JA. The theory of economic development. Massachusetts: Harvard University Press; 1934.

Schumpeter JA. Business cycles: A theoretical, historical, and statistical analysis of the capitalist process. New York: McGraw-Hill Book Company; 1939.

Schumpeter JA. Capitalism, socialism, and democracy. London: Routledge; 1942.

Schumpeter JA. Can capitalism survive? New York: HarperCollins Publishers; 1978.

Simon HA. Models of bounded rationality: Empirically grounded economic reason, vol. 3. Massachusetts: The MIT Press; 1982.

Simon HA. Bounded rationality and organizational learning. Organ Sci. 1991;2(1):125-34.

Smith A. The wealth of nations. New York: Random House, Inc.; 1937.

Sundararajan, A. From Zipcar to the sharing economy. Online article. Harv Bus Rev.. 2013. http://hbr.org/2013/01/fromzipcar-to-the-sharing-eco/(2015.03.14)

Teece DJ, Pisano G, Shuen A. Dynamic capabilities and strategic management. Strat Manag J. 1997;18(7):509-33.

Weitzman ML. The simple macroeconomics of profit sharing. Am Econ Rev. 1985;75(5):937-53.

Wolff EN. The rate of surplus value, the organic composition, and the general rate of profit in the US economy, 1947-67. Am Econ Rev. 1979;69(3):329-41.

Won-Chan J. Choice for the Future: Coupled Growth. Seoul: 21 Century Books; 2013.

Yun JJ, Won D, Hwang B, Kang J, Kim D. Analysing and simulating the effects of open innovation policies: Application of the results to Cambodia. Sci Publ Pol. 2015;42(1):1-18.

Zervas G, Proserpio D, Byers J. The rise of the sharing economy: Estimating the impact of Airbnb on the hotel industry, Boston U. School of Management Research Paper Series. 2014. p. 2013-6. 